\title{
OBITUARIES
}

Prof. N. E. Svedelius, For.Mem.R.S.

Prof. Nus Everhard Svedelius, the eminent Swedish botanist, died at Uppsala on August 2. He was born at Stockholm on August 5, 1873, of an old family noted for its scholarship and public service, which took its name from the small town of Sveden, in Dalecaria. Going to the University of Uppsala in 1895, he was later elected curator of the Stockholm nation. This student office gave him an early acquaintance with the business side of university affairs and led to his abiding interest in administration in which he played a prominent part at Uppsala.

Uppsala has always played a very prominent part in cryptogamic botany, for a long line of eminent botanists have made the different groups their special study. Svedelius, under the guidance of $\mathbf{F}$. R. Kjellmann, who was noted for his researches on Arctic algae, took up the study of those of the Baltic, which provided the subject of his doctorate thesis in 1901. After studying at Munich that year, he journeyed to Ceylon, the East Indies and Java, 1902-3, where he gained a knowledge of tropical algae which ever afterwards stood him in good stead; a paper on the algae of the coral reefs of Ceylon, 1906, was one result of these travels, but their influence is seen in his discussion of the discontinuous geographical distribution of some tropical and subtropical marine algae, 1924. He was a prolific writer on algology, treating practically every aspect of this wide field, but his most important contributions were on the anatomical structure and development, and on reduction divisions and alternation of generations in the Florideae. It may be said that Svedelius and his pupil J. H. Kylin, later of Lund, initiated the study of algal cytology at Uppsala.

In 1908, he found that, in the tetrasporangium of Martensia, the tetrad is formed by only one of the numerous cell nuclei. Working with Delesseria sanguinea in 1912-14 he confirmed Yamanouchi's discovery of alternation of generations with changes of nuclear phase in the red algae.

In 1915 he discovered that in Scianaia furcellata, which lacks tetraspores, meiosis sets in immediately after the fertilization of the female nucleus which had invaded an auxiliary cell; one of the four nuclei gives rise to the gonimoblast which has haploid nuclei. Then, in 1933, he showed that meiosis begins immediately after fertilization in Asparagopsis and Bonnemaisonia. In monospore cultures, 1937, he proved that in Lomentaria rosea, whero there are no sexual individuals, tetraspores are formed without meiosis, unlike $L$. clavellata, which is typically diplobiontic, having separate tetrasporous and sexual individuals. In 1942 he found that Galaxaura, closely related to Scianaia, has separate tetrasporous individuals. $\mathrm{He}$ finally reached the conclusion, therefore, that the sole criterion of a haplobiontic or diplobiontic development can no longer be regarded as of any great systematic importance.

Svedelius was soon regarded as among the foremost algological systomatists; indeed, so early as 1911 he wrote the section on Bangiales in Engler and Prantl's "Pflanzenfamilien".

It would probably be true to say that Svedelius used his extraordinarily wide knowledge of algology to note problems which needed to be solved if theories based on insufficient facts were not to hold continued sway. By selecting these for the most part, though in no wise neglecting other opportunities which came to hand, he deservedly gained his great reputation.

In 1914 he sueceeded $H$. $O$. Juel as professor of botany at Uppsala, and prælector of the University Garden. Juel had written a full account of Burser's herbarium and Svedelius saw it through the press. Burser, who died in 1639, left a hortus siccus of twenty-five volumes, the result of extensive continental journeys. This, one of the treasures of Uppsala Museum, had many vicissitudes before, surprisingly, reaching Uppsala-and then suffered the loss of two volumes in the great fire of 1702 . It contains many specimens of C. Bauhin which enabled Linnæus to recognize his types. It is of fundamental importance in botanical nomenclature which, however, does not do away with its intrinsic historical value.

Svedelius was an authority on the lives and works of his great predecessors and, not unexpectedly, of Linnaus. The old University Botanic Garden, which Linnæus had reorganized and made famous, was left to become scientifically dorolict after Gustav III had presented the gardens of the Royal Palace to the University on the urgent representation to him by C. P. Thunberg that the old garden was in a marshy district and otherwise unsuitable. Svedelius was one of the foremost of those who forced through a scheme in the early ' 20 's for rearranging the Garden as it was in Linnæus's time and to ensure its future care.

Like most Swedish botanists, Svedelius did a good deal to popularize the subject in articles, and also wrote a popular book.

Prof. Svedelius represented Sweden at many botanical congresses and was also personally well known from his visits to foreign institutions. His quiet demeanour, with apt comments when such were in place, together with his evident enjoyment of the humorous gained him general affection.

He held many foreign distinctions. In Britain he was foreign member of the Linnean Society (1917), and the Royal Society (1944), and honorary member of the Botanical Society of Edinburgh (1938).

JOHN RAMSBOTTOM

\section{Sir Arthur Fleming, C.B.E.}

THE death of Sir Arthur Fleming on September 14 will have saddened all who are concerned with the improvement of our national facilities for engineering education and training, and most of all those many thousands of men who were privileged to benefit from the schemes of apprenticeship which he pioneered within the Metropolitan-Vickers Elcctrical Co., I.td. (now, Associated Flectrical Industries (Manchester), Ltd.) more than fifty years ago.

Ho was born at Newport, Isle of Wight, in 188I, and was educated at the P'ortland Houso Academy there and at the Finsbury Technical College in London. After occupying positions with the London Elcctric Supply Corporation and a firm of instrument makers, he was selected by the British Westinghouse Co., lator Metropolitan-Vickers, Manchester, as one of the 'holy forty', to undergo a course of training 